whether he will not think it an intrusion: doubts which any editor who did wish for communications might dispel by making such an announcement as I have suggested.

R. R.

Lincoln's Inn.

NOTES UPON CUNNINGHAM'S HAND-BOOK OF LONDON.

St. Giles's Pound. - The exact site of this Pound, which occupied a space of thirty feet, was the broad space where St. Giles's High Street, 'Tottenham Court Road, and Oxford Street meet. The vicinity of this spot was proverbial for its profligacy; thus in an old song:-

"At Newgate steps Jack Chance was found, And bred up near St. Giles's Pound."

Dudley Court, St. Giles's. - This spot was once the residence of Alice Duchess of Dudley, in the reign of Charles the Second; and afterwards of the celebrated Lord Wharton. The mansion and gurdens were of considerable extent.

St. Giles's Hospital. - The celebrated Dr. Andrew Boorde rented for many years the Master's house. He is mentioned as its occupant in the deed of transfer between Lord Lisle to Sir Wymonde Carewe, dated in the last year of Henry the Eighth's reign.

Gray's Inn Lane. - Anciently called Portpoole. See the commission granted to the Master of the Hospital of St. Giles's, \&c. to levy tolls upon all cattle, merchandize, \&c., dated 1346, in Rymer's Fcedera.

Greut Queen Street, Lincoln's Inn. - Lord Herbert of Cherbury was one of the first inhabitants of this street, residing at the south side, near the east corner of Wild (or more properly Weld) Sireet, where he died in 1648 . The house is still standing, and is one of fifteen built in the third year of James the First. Powlet and Conway houses, also still standing, are among the said number. The celebrated Dr. Mead (d. 1754) resided in this street.

Turnstile Lane, Holborn. - Richard Pendrell, the preserver of Charles the Second, resided here in 1668. It is supposed that Pendrell, after the Restoration, followed the king to town, and settled in the parish of St. Giles, as being near the court. Certain it is that one of Pendrell's name occurs in 1702 as overseer, which leads to the conclusion that Richard's descendants continued in the same locality for many years. A great-granddaughter of this Richard was living in 1818 in the neighbourhood of Covent Garden. Richard Pendrell died in 1674 , and had a monument erected to his memory on the south-east side of the old church of St. Giles. The raising of the churchyard, subsequently, had so far buried the monument as to render it necessary to form a new one to preserve the nemory of this celebrated man. The black marble slab of the old tomb at present forms the base of the new one.

Eoward H. Rimbault.

Mrs. Cornelly's is stated, in vol. ii. p. 753., to be "the corner of Sutton Street," Soho Square, "now D'Almaine's." Mrs. Cornelly's was at the corner of Sutton Street, but has long been pulled down: the Catholic chapel in Sutton Street was Mrs. Cornelly's concert, ball, and masqueraderoom; and the arched entrance below the chapel, and now a wheelwright's, was the entrance for "chairs." D'Almaine's is two doors north of Sutton Street, and was built by Earl (?) Tilney, the builder of Wanstead House? The House in Soho Square has a very fine banqueting-room, the ceiling said to have been painted by Angelica Kauffinann. Tilney was fond of giving magnificent dinners, and here was always to be found "the flesh of beeves, with Turkie and other small Larks!"

Cock Lane. - The house in Cock Lane famous for its "Ghost" is still standing, and the back room, where "scratching Fanny" lay surrounded by princes and peers, is converted into a gas meter manufactory.

Naso.

\section{FOLK LORE.}

Easter Eggs. - The custom of presenting eggs at Easter is too well known to need description; but perhaps few are aware that, like many other customs of the early Church, it had its origin in paganism.

Sir R. K. Porter (Travels, vol. i. p. 316.) mentions that at a period of the year corresponding to Easter, "the Feast of nooroose, or of the waters," is held, and seems to have had its origin prior to Mahometanism. It lasts for six days, and is supposed to be kept in commemoration of the Creation and the Deluge - events constantly synchronised and confounded in pagan cosmogonies. At this ferst eggs are presented to friends, in obvious allusion to the Mundane egg, for which Ormuzd and Ahriman were to contend till the consummation of all things.

When the many identities which existed between Druidism and Magianism are considered, we ean hardly doubt that this Persian commemoration of the Creation originated our Easter eggs. G.J.

Buns. - It has been suggested by Bryant, though, I believe, not noticed by any writer on popular customs, that the Good Friday cakes, called Buns, may have originated in the cakes used in idolatrous worship, and impressed with the figure of an $o x$, whence they were called Bowv. The cow or bull was likewise, as Coleridge (Lit. Rem. vol, ii. p. 252.) has justly remarked, the 
symbol of the Cosmos, the prolific or generative powers of nature.

G. J.

Gloucestershire Custom. - It is a custom in Gloucestershire, and may be so in other counties, to place loose straw before the door of any man who beats his wife. Is this a general custom?and if so, what is its origin and meaning?

Curious Custom. - The custom spoken of by "Pweca" (No.11. p. 173.) was also commonly practised in one or two places in Lancashire some ten or twelve years back, but is now, I believe, obsolete. The horse was played in a similar way, but the performer was then called "Old Balls." It is no doubt a vestige of the old "hobby-horse," -as the Norwich "Snap," who kept his place in the procession of the mayor of that good city till the days of municipal reform, was the last representative of his companion the dragon.

J. T.

[Nathan also informs us "that it is very common in the West Riding of Yorkshire, where a ram's head often takes the place of the horse's skull. Has it not an obvious connection with the "hobby-horse " of the middle ages, and such mock pageants as the one described in Seott's Abbot, vol. i. chap. 14, ; the whole being a remnant of the Saturnalia of the ancients? ']

QUERIES.

\section{WHITE HART INN, SCOLE.}

In Songs and other Poems, by Alex. Brome Gent. Lond. 12mo. 1661, there is (at p, 123.) a ballad upon a sign-post set up by one Mr. Pecke, at Skoale in Norfolk. It appears from this ballad, that the sign in question had figures of Bacchus, Jiana, Justice, and Prudence, "a fellow that's small, with a quadrant discerning the wind," Temperance, Fortitude, Time, Charon and Cerberus. This sign is noticed in the Journal of Mr. E. Browne (Sir Thomas Browne's Works, ed. Wilkin, i. 53.). Urder date of 4th March, 166364, he says :- "About three mile further I came to Scoale, where is very handsome inve, and the noblest sighne post in England, about and upon which aro carved a great many stories, as of Charon and Cerberus, of Acteon and Diana, and many other; the sighne it self is the white harte, which hangs downe carved in a stately wreath." Blomefield, in his History of Norfolh (8vo. edit. i. 130.), speaking of Osmurdestone or Scole, has the following passage: -

"Here are two very good inns for the entertainment of travellers; the White IIart is much noted in these parts, being called, by way of distinction, Scole Inn; the house is a large brick building, adorned with imagery and carved work in several places, as big as the life. It was built in 1655 , by John Peck, Esq., whose arms impaling his wife's, are over the porch door. The sign is very large, beautified all over with a great number of images of large stature carved in wood, and was the work of one Fairchild; the arms about it are those of the chief towns and gentlemen in the county, viz. Norwich, Yarmouth, Duke of Norfolk, Earl of Yarmouth, Bacon of Garboldisham, Hobart, Conwaleas, impaling Buhton, Teye, Thurston, Castleton, and many otliers; Peck's arms are arg. on a chevron ingrailed, gul. three croslets pattee of the field; his wife's are arg., a fess between two crescents in chief, a lion rampant in base gul., which coat I think is borne by the name of Jetheston. Here was lately a very round large bed, big enough to hold fifteen or twenty couple, in imitation (I suppose) of the remarkable great bed at Ware. The house was in all things accommodated, at first, for large business; but the road not supporting it, it is in much decty at present; though there is a good bowling-green and a pretty large garden, with land sufficient for passengers ${ }^{2}$ horses. The business of these two inns is much supported by the annual cock-matehes that are here fought."

In Cruttwell's Tour through the whote Island of Great Britain (Lond. 12mo. 180I), vol. v. 208., is the following: -

"Osmondeston, or Schole. The inn here was onee remarkable for a pompous sign, with ridiculous ornaments, and is said to have cost a thousand pounds; long since decayed."

I shall be glad to be referred to any other notices of this sign, and an desirous of knowing if any drawing or engraving of it be extant.

Cambridge, 21st Jan. 1350.

C. H. Coorer.

\section{PASSAGES FROM POPE;}

In addition to the query of "P. C. S. S." (No. 13. p. 201.), in which I take great interest, I would beg leave to ask what evidence there is that Quarles had a pension? He had, indeed, a small place in the household of James the First's queen, Anne; and if he had a pension on her death, it would have been from James, not from Charles.

I would also, in reference to Pope, beg leave to propound another query.

In the "Imitation of the 2nd Sat. Book I. of Horace," only to be found in modern editions, but attributed, I fear, too justly to Pope, there is an allusion to "poor E-s," who suffered by "the fatal steel," for an intrigue with a royal mistress. E-s is no doubt fohn Ellis, and the royal mistress the Duchess of Cleveland. (See Lord Dover's Introduction to the "Ellis Correspondence," and "Anecdotes of the Ellis Family," Gent. Mag. 1769. p. 328.) But I cannot discover any trace of the circumstances alluded to by Pope. Yet Ellis was a considerable man in his day ; he had been Secretary to the Lord-Lieutenant of Ireland in the reign of Charles II., and was UnderSecretary of State under William III.; he is said to have afterwards sunk into the humbler character 